\title{
Antibodies against pseudorabies virus in feral swine in southeast Brazil
}

\author{
[Anticorpos contra o vírus da doença de Aujeszky em javalis no estado de São Paulo]
}

\author{
E.M.S. Cunha, A.F.C. Nassar, M.C.C.S.H. Lara, J.G. Bersano, E.M.C. Villalobos, J.C.F. Oliveira \\ Centro de Pesquisa e Desenvolvimento de Sanidade Animal - Instituto Biológico \\ Av. Conselheiro Rodrigues Alves, 1252 \\ 04014-002 - São Paulo, SP
}

\begin{abstract}
Serum samples collected from 358 wild boars (Sus scrofa) in breeding farms in São Paulo, southeast Brazil, from 1998 to 2001, were tested for antibodies against pseudorabies virus (PRV) by means of serum neutralization (SN) and enzyme-linked immunobsorbent assay (ELISA). Seropositive animals were detected in three of seven herds analyzed. Overall seroprevalence as assessed by SN was 30.7\%, ranging from $25.2 \%$ to $100 \%$ for the herds that presented seropositive animals. Indirect ELISA detected lower seroprevalence (19.3\%). Sensitivity and specificity of ELISA were equal to $57.3 \%$ and $97.6 \%$, respectively. Agreement was equal to $85.2 \%(\mathrm{P}<0.0001)$. These results showed that PRV infections occurred in farmed feral swine in southeast Brazil, and affect pseudorabies eradication program.
\end{abstract}

Keywords: wild boar, Sus scrofa, pseudorabies virus, Aujeszky's disease virus, antibodies

\section{RESUMO}

Soros de 358 javalis (Sus scrofa), criados em sistema de semiconfinamento em propriedades do estado de São Paulo, foram coletados entre 1998 e 2000 e testados para anticorpos contra o vírus da doença de Aujeszky (VDA), pela técnica de soroneutralização (SN) e ensaio imunoenzimático (ELISA). Foram detectados animais soropositivos em três das sete propriedades analisadas. Do total de javalis testados, $30,7 \%$ apresentaram anticorpos neutralizantes contra o VDA, com variação de $25,2 \%$ a $100 \%$ nas propriedades com animais sororreagentes. O ELISA detectou menor número de sororeagentes (19,3\%), sendo a sensibilidade e a especificidade $57,3 \%$ e $97,6 \%$, respectivamente, e a correlação observada de $85,2 \%(P<0,0001)$. Os resultados mostram que a infecção pelo vírus da doença de Aujeszky ocorre em criações de javalis no estado de São Paulo, e compromete o sucesso de um futuro programa de erradicação da doença na região.

Palavras-chave: javali, Sus scrofa, virus da doença de Aujeszky, anticorpos

\section{INTRODUCTION}

Aujeszky's disease, also known as pseudorabies, is caused by an alphaherpesvirus and affects pigs at all ages. High mortality in naïve newborn piglets and abortion in pregnant sows cause economic losses for the swine industry. As all herpesviruses, pseudorabies virus (PRV) in natural hosts is able to establish latent infection, which can be reactivated under experimental or natural conditions (Beran et al., 1980). After stressful conditions, latent virus can be reactivated and shed in the environment. In domestic herds, pseudorabies virus is transmitted to susceptible pigs by aerosols from the respiratory tract of infected animals, or through exposure to virus present in secretions and excretions (McFerran and Dow, 1964).

Recebido em 10 de maio de 2004

Aceito em 3 de janeiro de 2006

E-mail: cunha@biologico.sp.gov.br 
Serological surveys for PRV antibodies and PRV isolation in domestic swine have been reported in many southern and southeastern states of Brazil (Hipolito et al., 1960; Romero et al., 1984; Kotait et al., 1986). The swine industry of countries that have the disease may be economically affected due to sanitary barriers imposed to international trade.

Free range swine populations are reservoirs of many diseases including brucellosis, classical swine fever, leptospirosis and Aujeszky's disease (Gresham et al., 2002). As for Aujesky's disease in wild boars (Sus scrofa), occurrence of clinical illness and prevalence of latent infections is unknown.

Experimentally infected adult wild swine show little or no clinical disease, but these animals are able to transmit the virus. Infection by Aujeszky's disease virus occurs under natural conditions in wild boars, as demonstrated by detection of serum antibodies to PRV (Van der Leek et al., 1993; Albina et al., 2000), and by isolation of the virus both from oropharingeal and genital swabs of feral boars and sows after dexametasone-induced immunosupression (Romero et al., 1997). Mechanisms of indigenous PRV natural transmission in feral swine populations are little known. Isolation of PRV from genital and respiratory tracts of experimentally immunosupressed feral swine may indicate various routes of transmission (Romero et al., 1997).

Many countries in Europe are free from Aujeszky's disease and some have begun eradication programs. The State-Federal-Industry pseudorabies eradication program in USA began in 1989 with the aim of eradicating PRV by the year 2000 (Romero et al., 2001).
Wild swine population must be considered as a risk for the spread of many diseases, including pseudorabies (Annelli, 1995; Gresham et al., 2002), and a threat for eradication programs. Serological evidence of PRV infection in feral swine populations has been reported in the United States (Leek et al., 1993; Gresham et al., 2002;) and in Europe (Albina et al., 2000). Thus, there is a major concern in monitoring the epidemiological situation of wild boars, especially when control measures are to be determined for domestic pigs.

During the last few years, there was an increase in the number of wild boar herds in Sao Paulo, Brazil. Therefore, a serological study in feral swine herds has been initiated in this country. The objective of this paper is to report findings regarding pseudorabies virus antibodies in feral swine (Sus scrofa) from herds in cities of the State of Sao Paulo, southeast Brazil.

\section{MATERIALS AND METHODS}

Blood samples were collected from 358 wild boars from seven herds of the State of São Paulo, Brazil (Table 1), from 1998 to 2001. Sera were stored at $-20^{\circ} \mathrm{C}$ until analyzed. All sera were tested using an enzyme-linked immunosorbent assay (ELISA) using a test developed by Centro Nacional de Pesquisa de Suínos e Aves EMBRAPA. It is an indirect ELISA using PRV antigen and cell culture antigen-coated microtritation plates. Antibodies in serum samples bind to the antigens and are detected by a KPL peroxidase-labeled purified goat antibody against swine IgG. Results were interpreted as positive or negative.

Table 1. Antibodies against pseudorabies virus (PRV) in wild boars in Sao Paulo, Brazil, from 1998 2001

\begin{tabular}{lcccc}
\hline City & Year sampled & Number tested & Number positive & Frequency (\%) \\
\hline Olímpia & 1998 & 6 & 6 & 100 \\
Monte Alegre do Sul & 1998 & 6 & 0 & 0 \\
Serra Azul & 2000 & 16 & 0 & 0 \\
Paraguaçu Paulista & 2000 & 226 & 57 & 25.2 \\
Santa Barbara d'Oeste & 2001 & 84 & 47 & 55.9 \\
Serra Azul & 2001 & 18 & 0 & 0 \\
Piracaia & 2001 & 2 & 0 & 0 \\
\hline
\end{tabular}


Serum samples were heat-inactivated at $56^{\circ} \mathrm{C}$ for $45 \mathrm{~min}$ and then assayed in a virus neutralization test with 100 PRV median tissue culture infective doses (TCID50).

Diagnostic and proportion of agreement were performed and estimated using the spreadsheet DAG_Stat (Mackinnon, 2000) to provide a comprehensive range of statistics calculable from $2 \times 2$ tables, which are useful in evaluating diagnostic tests and inter-rate agreement. Data entered were frequencies arising from the crosstabulation of the test being investigated (ELISA) against the criterion (serum neutralization - $\mathrm{SN}-$ Gold Standard) for the presence or absence of the disorder to which the test is supposedly sensitive.

\section{RESULTS}

The results in Table 1 show that wild boar presenting antibodies to PRV were detected in three of seven herds. Overall seroprevalence by SN was $30.7 \%$; ranging from $25.2 \%$ to $100 \%$ for the three herds showing seropositive animals. Table 2 shows the results obtained in the application of two assays for antibodies against PRV. Indirect ELISA showed a lower seroprevalence $(19.3 \%)$. The characteristics of diagnostic tests and inter-rate agreement were calculated from Table 2. The sensitivity and specificity of ELISA were equal to $57.3 \%$ and $97.6 \%$, respectively; observed agreement was equal to $85.2 \%(\mathrm{P}<0.0001)$.

Table 2. Cross tabulation of enzyme-linked immunobsorbent assay (ELISA) against serum neutralization $(8 \mathrm{~N})$ test

\begin{tabular}{lccc}
\hline \multirow{2}{*}{ SN } & \multicolumn{3}{c}{ ELISA } \\
\cline { 2 - 4 } & Positive & Negative & Total \\
\hline Positive & 63 & $47^{*}$ & 110 \\
Negative & $6^{*}$ & 242 & 248 \\
Total & 69 & 289 & 358 \\
\hline
\end{tabular}

*McNemar's test (Chi Square=30.2; $\mathrm{P}<0.0001)$.

\section{DISCUSSION}

The serological survey on farmed wild boar presented is the first study on PRV virus infection of this specie in herds of the State of Sao Paulo. The survey described can increase the concern of the veterinary services and farmers on infectious diseases that may affect wild boars and may be transferred to domestic pigs. This major concern also leads to the decision to include serological monitoring of farmed wild boars in a surveillance program carried out on domestic pigs for notifiable disease.

PRV seroprevalence in farmed wild boars in the present trial was $30.7 \%$. This finding are in agreement with other similar studies performed in the USA and Europe (Van der Leek et al., 1993; Gresham et al., 2002; Zupancic et al., 2002). However, studies performed in Germany in the 1990's report that $1.7-8.9 \%$ wild boars had antibodies against ADV, showing a lower seroprevalence than what was reported here (Lutz and Wurm, 1996; Muller et al., 1998). Albina et al. (2000) in a serological survey on classical swine fever, Aujeszky's disease and porcine reproductive and respiratory syndrome viruses in both farmed and hunted wild boars in France also reported lower PRV seroprevalence, equal to $1.2 \%$ and $5.5 \%$ respectively.

It is well known that wild boars are natural reservoirs for Aujesky's disease (Gresham et al., 2002). However, the actual importance of these animals as infection sources for domestic swine is controversial. Van der Leek et al. (1993) detected $34.8 \%$ PRV seropositive wild boars all over Florida and concluded that this population may seriously undermine efforts to eradicate the virus from domestic swine population in the USA. A survey compared the prevalence of Brucella suis and Pseudorabies virus antibodies in feral swine populations in South Carolina in two different periods and reported an increase in PRV infection, 20\% from 1975 to 1987 , and 42\% from 1987 to 1999 . It also suggested that these animals may constitute a reservoir of infectious agents transmissible to domestic swine, presenting a risk to local domestic livestock (Gresham et al., 2002). However, Romero et al. (2001), studying the routes of transmission involved in natural infection by pseudorabies virus indigenous to free-range feral swine, concluded that the respiratory route is not the main route of transmission, and that transmission of the virus to domestic pigs is unlikely, posing only a limited risk to the success of eradication programs for the disease.

The PRV antibodies of all samples were detected by means of SN test and ELISA performed using a test developed by CNPSA- EMBRAPA. Banks 
and Cartwright (1983) compared four tests used in the detection of antibodies to Aujeszky's disease virus in porcine sera and concluded that ELISA sensitivity was greater than SN. ELISA described here in the detection of PRV antibodies in domestic swine sera shows a higher correlation with $\mathrm{SN}$ and is routinely used in monitoring swine herds. On the other hand, results show that ELISA was less sensitive than $\mathrm{SN}(\mathrm{SR}=58.9 \%)$ when used in wild boar serum samples. The poor response of indirect ELISA is in agreement with similar results published elsewhere (Schmitt et al., 1991; Hahn et al., 1997). According to Hahn et al. (1997) the poor response of ELISA could be due to variation in specific viral antigens between the feral pig strains and the domestic pig strain, however, neutralizing titers were more comparable, suggesting that neutralizing epitopes are not different.

The ELISA is easy to perform and detect infection earlier than SN. However, our results suggest that the performed ELISA should not used by monitoring PRV antibodies in wild boars.

These data show that PRV infections occur in farmed feral swine in southeast Brazil. Thus, these animals may be a source for the virus to infect domestic pigs and there is an urgent need for a risk assessment study to elucidate the importance of infected feral swine in a pseudorabies eradication program.

\section{REFERENCES}

ALBINA, E.; MESPLÈDE, A.; CHENUT, G. et al. Serological survey on classical swine fever (CSF), Aujeszky's disease (AD) and porcine reproductive and respiratory syndrome (PPRS) virus infections in French wild boars from 1991 to 1998. Vet. Microbiol., v.77, p.43-57, 2000.

ANNELLI, J. Does ADV in feral swine interfere with the eradication plans in domestic swine. In: INTERNATIONAL SYMPOSIUM ON THE ERADICATION OF AUJESZKY'S DISEASE (PSEUDORABIES) VIRUS, 2., 1995, Copenhagen. Proceedings... Copenhagen, Denmark, 1995. p.19. (Abstract).

BANKS, M.; CARTWRIGHT, S. Comparison and evaluation of four serological tests for detection of antibodies to Aujeszky's disease virus. Vet. Rec., v.113, p.38-41, 1983.

BERAN, G.W.; DAVIES, B.; ARAMBULO, P.V. et al. Persistence of pseudorabies virus in infected swine. J. Am. Vet. Med. Assoc., v.176, p.998-100, 1980

GRESHAN, C.S.; GRESHAN, C.A.; DUFFY, M.J. et al. Increased prevalence of Brucella suis and pseudorabies virus antibodies in adults of an isolated feral swine population in coastal south Carolina. J. Wildl. Dis., v.38, p.653-656, 2002.

HAHN, E.C.; PAGE, G.R.; HAHN, P.S. et al. Mechanisms of transmission of Aujesky's disease virus originating from feral swine in the USA. Vet. Microbiol., v.55, p.123-130, 1997.

HIPOLITO, O.; SILVA, J.M.L.; BATISTA JUNIOR, J.A. et al. Doença de Aujeszky em suínos no Estado de Minas Gerais. Arq. Esc. Sup. Vet., v.13, p.61-67, 1960.

KOTAIT, I.; CUNHA, E.M.S.; QUEIROZ, L.H. et al. Doença de Aujeszky no Estado de Sao Paulo: inquérito sorológico em plantéis de reprodutores suínos realizado no período de 1982-1986. Arq. Inst. Biol., v.53, p.71-73, 1986.

LEEK, M.L.; BECKER, H.N.; PIRTLE, E.C. et al. Prevalence of pseudorabies (Aujeszky's disease) virus antibodies in feral swine in Florida. J. Wildl. Dis., v.29, p.403-409, 1993.

LUTZ, W.; WURM, R. Serologische untersuchungen zum nachweis von antikorpern gegen viren des seuchenhafen spätaborts, der Aujeszkyschen krankheit, der Europäischen Schweinepest und porzine parvoviren beim wildschwein (Sus scrofa, L., 1758) in NordrheinWestfalen. Z. Jagwiss, v.47, p.123-133, 1996.

MACKINNON, A. A spreadsheet for the calculation of comprehensive statistics for the assessment of diagnostic tests and inter-rater agreement. Comput. Biol. Med., v.30, p.127-134, 2000 .

MCFERRAN, J.B.; DOW, C. The excretion of Aujeszky's disease virus by experimentally infected pigs. Res. Vet. Sci., v.5, p.405-410, 1964.

MULLER, T.; TEUFFERT, J.; POSSAR, C. et al. Pseudorabies in the European wild boar from eastern Germany. J. Wildl. Dis., v.34, p.251-258, 1998. 


\section{Cunha et al.}

ROMERO, C.H.; MEADE, P.; SANTAGATA, J. et al. Genital infection and transmission of pseudorabies virus in feral swine in Florida, USA. Vet. Microbiol., v.55, p.133-139, 1997.

ROMERO, C.H.; MEADE, P.; SHULTZ, J.E. et al. Venereal transmission of pseudorabies viruses indigenous to feral swine. J. Wildl. Dis., v.37, p. 289-296, 2001.

ROMERO, C.H.; ROWE, C.A.; PROVENZANO, G.I. et al. Distribuição e prevalência de anticorpos precipitantes para o vírus da doença de Aujeszky em plantéis de suínos no estado de Santa Catarina 1987. 1987. Pesq. Vet. Bras., v.4, p.123-127, 1984.

SCHMITT, B.J.; OSORIO, F.A.; STROUP, W.W. et al. A comparision of differential diagnostic tests to detect antibodies to pseudorabies glycoproteins $\mathrm{gX}, \mathrm{gI}$ and gIII in naturally infected feral pigs. 1991. J. Vet. Diagn. Invest., v.3, p.344-345, 1991.

VAN DER LEEK, M.L.; BECKER, H.N.; PIRTLE, E.C. et al. Prevalence of pseudorabies (Aujeszky's disease) virus antibodies in feral swine in Florida. J. Wildl. Dis., v.29, p.403-409, 1993.

ZUPANCIC, Z.; JUKIC, B.; LOJKIC, M. et al. Prevalence of antibodies to classical swine fever, Aujeszky's disease, porcine reproductive and respiratory syndrome, and bovine viral diarrhea viruses in wild boars in Croatia. Vet. Med. B. Infect. Dis. Vet. Public Health, v.49, p.253-256, 2002. 